\title{
A Comparative Analysis of the Credit Rating System Between China and the United States
}

\author{
Xinrui $\mathrm{Li}^{1, *}$ \\ ${ }^{1}$ School of Economics and Management, Tianjin University of technology and education, Tianjin, China, 300222 \\ *Corresponding author. Email:xinrui9919@foxmail.com
}

\begin{abstract}
China's bank credit rating system, as one of the main aspects of bank control, has not yet met the international requirements for accurate measurement and effective management of credit risk, and is in urgent need of reform and improvement. Based on the relevant theories of bank credit rating, this paper makes a comparative analysis of the credit rating systems of Chinese and American banks, and then discusses the reasons for the differences between Chinese and American banks according to the policy and legal environment and other external factors affecting the rating system. Finally, aiming at the existence of our country bank credit rating system in the management ideas and technology are located, such problems as imperfect credit system building, this paper puts forward the only clear the credit rating industry in a new financial market environment standard of work, promote the orderly development of the industry to perfect our country bank credit rating system[1].
\end{abstract}

Keywords : Chinese American Commercial Bank, Credit Rating, The Rating Method

\section{INTRODUCTION}

A bank's credit rating is a judgment of a bank's ability to assume general unsecured debt. Bank credit rating is mainly used to provide investors and trading partners with a judgment of the overall credit level of the bank. Bank internal credit rating is based on credit risk and is an important means to control, detect and prevent credit risk. Compared with the credit rating system of international banks, the credit rating system of Chinese banks is at a lower level, and relevant laws and regulations need to be constantly improved and standardized. This paper mainly focuses on the concept and characteristics of the Chinese bank credit rating system, and compares it with the American credit rating system. Some suggestions and measures are put forward to standardize the credit rating system of Chinese commercial banks scientifically and systematically.

\section{COMPARISON OF THE CREDIT RATING SYSTEMS OF CHINESE AND AMERICAN COMMERCIAL BANKS}

In recent years, unstable factors in the financial market have led to a large number of risk management problems in banks, which is a major challenge to the credit rating industry of Chinese banks. The new "Basel
Accord" strengthens the supervision and supervision of regulatory institutions and puts forward higher requirements for the future risk management of Chinese banks[3].

\subsection{Comparison of legal system construction}

As one of the most reputable countries in the world, the United States has incorporated a series of processes from development to the use of credit products into its legal system. And the modern credit rating in the United States began when the laws and regulations about credit rating were relatively perfect. Therefore, the United States currently has a relatively complete credit rating management system, and the construction of these legal systems has become the cornerstone of the steady development of the American financial industry.

Since 2014, the construction of China's social credit system has gradually taken shape, and remarkable progress has been made in the construction of the credit system. However, social dishonesty is still widespread, and problems in some areas and regions are still prominent. The fundamental reason is that the lag of the rule of law construction has become the main crux of the difficulty in deepening the construction of China's credit system. The blacklist standards are inconsistent, the legal binding force of disciplinary measures is not 
strong, and some clauses are in conflict with the existing provisions. And due to the lack of legal definition and protection of credit information, the disclosure and abuse of personal credit information is serious, which infringes the legitimate rights and interests of credit subjects.

\subsection{Comparison of government regulatory departments}

The U.S. financial markets have two major regulators: the Securities and Exchange Commission (SEC) and the Commodity Futures Commission. The key for the Us regulatory system to play its effective regulatory role is to divide the scope of supervision into business functions rather than organizational boundaries.[4] This ensures consistent regulation of businesses in a mixed financial system and prevents chaotic arbitrage in the development of similar businesses. It greatly promoted the development of the American financial market and the emergence of financial innovation.

China's banking industry consists of the China Banking Regulatory Commission, the China Securities Regulatory Commission and the China Insurance Regulatory Commission, which together constitute the national financial regulatory system. Commercial banks in our country have been transformed from banks. In addition, compared with the DUAL banks in the United States, Chinese banks have less regulatory freedom, and Chinese banks are not free to set prices. Therefore, in the face of borrowers with different credit conditions, banks can only lend to them in accordance with the unified interest rate. China's non-performing loan balance and non-performing loan ratio are at a high level. This shows that China still has a long way to go in terms of bank credit supervision and risk management.

\subsection{Comparison of rating methods}

American commercial banks take the analysis of financial statements of enterprises as the core part of credit rating, and their credit staff is equipped with abundant accounting knowledge and ability to analyze the solvency of enterprises from the perspective of financial statement users. Furthermore, the risk measurement model is widely used in the quantitative analysis of credit risk in American commercial banks[6].

Comparatively speaking, the credit rating system of Chinese commercial banks is relatively primitive, and the commonly used credit risk evaluation methods mainly include expert rating method and judgment analysis method.

The expert evaluation method is the most traditional credit rating method. Its principle is to divide the credit of the borrower into several assessment objectives, and the bank staff can judge the credit status of the borrower by comprehensively assessing each objective. Common "5C" evaluation method, "5P" evaluation method and "5W" evaluation method are commonly used (see Table 1 for details). Due to the subjective factors of expert analysis method, the reliability of expert analysis results is low.

Table 1 Expert evaluation methods

\begin{tabular}{|c|c|c|c|c|c|}
\hline Methods & Goal 1 & Goal 2 & Goal 3 & Goal 4 & Goal 5 \\
\hline $5 \mathrm{C}$ & Moral & $\begin{array}{l}\text { Operating } \\
\text { ability }\end{array}$ & Capital asset & Collateral & Cash flow \\
\hline $5 \mathrm{P}$ & Personal factor & Fund use & $\begin{array}{c}\text { Repayment } \\
\text { source }\end{array}$ & $\begin{array}{c}\text { Creditor's } \\
\text { rights } \\
\text { guarantee }\end{array}$ & $\begin{array}{c}\text { Enterprise } \\
\text { prospect }\end{array}$ \\
\hline $5 \mathrm{~W}$ & Borrower & Loan purpose & $\begin{array}{c}\text { Repayment } \\
\text { period }\end{array}$ & Security & How \\
& & repayment \\
\hline
\end{tabular}

\section{PROBLEMS EXISTING IN CHINA'S BANK CREDIT RATING}

\subsection{Lack of correct scientific ideas}

At present, in most of China's banks, many employees have insufficient understanding of the modern financial market, the bank department is short of high-quality talents, and some employees are not high quality. Department rules and regulations are not sound, leading to cannot follow the principle of employees, employees for their own behavior is not responsible for, all kinds of illegal operations, the phenomenon such as unauthorized status often appear, such as part of the implementation of the repair department too much discretion, machiavellian credit phenomenon appeared in private, even violate the original intention of "punishing presses to the letter", formed the new power rent-seeking risk. 


\subsection{Lack of advanced credit rating management technology}

At present, the most widely used credit risk measurement models in the world are: KMV model, credit measurement model, macro simulation model, etc. Market information[2] can be reflected in these models in time, and the models have a strong predictability. However, China is relatively backward in the application and management technology of the credit rating model, which needs further development.

\subsection{Lack of a perfect social credit system}

The construction of the social credit system includes public credit system and market credit system. The former is mainly established by local governments and industrial departments, while the latter is established by various enterprises, industrial organizations and third-party credit service agencies. The market credit system is a spontaneous act of market subjects. Due to the limited users and the lack of transparency in credit rating, its objectivity and fairness will be questioned. With the continuous development of China's market economy, the rating status of enterprises is difficult to be truly reflected, and the authenticity of the financial data of enterprises is low. In addition, there is insufficient understanding of the importance of the credit rating system at the grassroots level, and the enthusiasm to integrate financial data is not high. Results in incomplete data of bank credit rating system.

\section{STRATEGIC SUGGESTIONS ON THE DEVELOPMENT OF CREDIT RATING OF CHINESE BANKS}

\subsection{Improve the construction of the legal system of credit rating}

Perfecting the construction of a credit rating legal system is one of the important guarantees to maintain the stability of the financial market. Only by strengthening legislation and standardizing the financial behavior of the banking industry can the order of China's financial market be better maintained. For example, to strengthen the openness and sharing of public credit data legislation. Opening public credit data is a natural extension of government information disclosure and a legal obligation of the government.

Break it industry data protection, break the departmental monopoly and blockade of credit information, not only to establish and improve data open idea, open system also have to build public data, from the legal norm and safeguard the credit opening and sharing of data resources, establish the people credit database, to promote scientific, digital bank credit rating.

\subsection{Improve bank credit rating management technology}

Now it has stepped into the era of big data. The concept of big data is an extension of the traditional concept of data and a supplement to the original data analysis technology. It is necessary for banks to make full use of big data technology to improve and reshape customer credit rating system, whether it is for internal development or to cope with external challenges.

Applying big data technology, the credit rating systems of banks can be further improved and innovated. Through a series of quantitative indicators, the bank credit rating system evaluates the credit status of customers and predicts whether customers are able or willing to fulfill their lending responsibilities after the lending relationship with the bank. With the gradual implementation of Basel NEW Capital Accord, Chinese banks should build their own internal rating system to realize the effective measurement of risk parameters such as customer default probability, default loss rate and default risk exposure.

At the same time, banks still need to strengthen the development of credit rating professional colleges, introduce advanced credit rating management technology, establish an advanced credit rating measurement model[5].

\subsection{Improve the method of credit rating investigation}

In the process of credit rating investigation, credit officers are more familiar with their peers, so it is easier to become a mere formality when supervising the investigation. The evaluation can be carried out by a group, and the joint investigation by professional credit personnel can be carried out to investigate and analyze the rating object. A combination of questionnaire survey and field investigation can be adopted to select the key indicators that can most accurately reflect the operating conditions of banks under the condition of ensuring the accuracy of survey results and basic information.

\section{CONCLUSION}

Through the comparative analysis of the credit rating system of Chinese and American banks, it is found that there is a big gap between Chinese and American banks. In contrast, Chinese banks have problems such as lack of correct scientific ideas, lack of advanced credit rating management technology, lack of more mature credit rating measurement model. After further analysis, it is found that there are many reasons for the gap between Chinese and American banks. Therefore, the paper concludes that under the new financial environment, China's bank credit rating system should be perfected in the risk management organization system. In addition to 
perfecting the construction of the credit rating legal system, improving bank credit rating management technology, and appropriately using professional data and methods provided by external rating agencies, China should also learn from the advanced experience of peers while combining the actual national conditions.

\section{ACKNOWLEDGMENTS}

In the process of preparing paper materials and writing the paper, my thesis teacher gave me careful and detailed guidance on both format and content, which greatly improved my ability in organizing academic language.Here, I would like to express my sincere thanks to Miss Han.

At the same time, I also want to thank my parents. I can't repay you for your kindness. Your health and happiness will always be my biggest wish! At the moment when this paper is about to be completed, I feel very excited. After all, from the beginning of the project to the final completion of the paper, countless respectable friends have given me help, and also express my sincere thanks to them!

\section{REFERENCES}

[1] Carmen Broto, Luis Molina. Sovereign ratings and their asymmetric response to fundamentals[J]. Journal of Economic Behavior and Organization,2016,130.

[2] Haoshen $\mathrm{Hu}$, Thomas Kaspereit, Jörg Prokop. The information content of issuer rating changes: Evidence for the G7 stock markets[J]. International Review of Financial Analysis,2016,47.

[3] Wang Chaolong. Status quo and countermeasures of credit risk management of commercial banks [J]. Modern Enterprise,2016(02):53-54.

[4] Mark Beasley,Bruce Branson,Don Pagach. An analysis of the maturity

and strategic impact of investments in ERM[J]. Journal of Accounting and

Public Policy,2015,34(3).

[5] Silvia Angilella,Sebastiano Mazzù. The financing of innovative SMEs: A multicriteria credit rating model[J]. European Journal of Operational Research,2015,244(2).

[6] Liu Shida, Wang Hao, Zhang Ming. Credit rating effectiveness and regulatory dependence: evidence from interbank certificates of deposit [J]. Acta economic sinica,2018,5(01):17-37. 